\title{
WATER RESOURCES EXPLORATION AND MANAGEMENT BASED ON REMOTE SENSING AND GEOPHYSICAL DATA ANALYSIS: AL-NAQAB WATERSHED, EAST CENTRAL SINAI, EGYPT
}

\author{
Usama Saad Abdelhamid MASSOUD ${ }^{1)}$, Hassan Mohamed El-SHAYEB ${ }^{2)}$, \\ Mohamed El-Said Mohamed MEBED ${ }^{4)}$, Sultan Awad Sultan ARAFFA ${ }^{1)}$, \\ Hamada Salama Abd El-HADY 1) * and Hamdy Ahmed El-DESOUKY 2, 3)
}

\author{
1) Geothermal and Geoelectric Laboratory, Geomagnetic and Geoelectric Department, National Research Institute of Astronomy and \\ Geophysics, El-Marsad street, Helwan, Cairo, Egypt \\ 2) Geology Department, Faculty of Science, Menoufia University, 32721, Shebin El Kom, Menoufia, Egypt \\ 3) Petroleum and Mining Geology, Faculty of Advanced Basic Sciences, Galala University, 43511 New Galala City, Egypt. \\ 4) General Administration of Geophysics, The Egyptian Mineral Resource Authority, 3 Salah Salem street, Abbasyia, Cairo, Egypt
}

*Corresponding author's e-mail: geophyhamada@yahoo.com; hamada.salama@nriag.sci.eg.

\begin{tabular}{l}
\hline ARTICLE INFO \\
\hline Article history: \\
Received 8 December 2020 \\
Accepted 24 February 2021 \\
Available online 12 March 2021 \\
\hline
\end{tabular}

Keywords:

Magnetic

Geoelectric

Remote sensing

GIS

Groundwater

Sinai

Egypt

\begin{abstract}
This study integrates remote sensing and geophysical data to identify the hydrological conditions of the Naqab reservoir watershed. The main objectives of this study are identification and the interpretation of subsurface structures and their impact on groundwater flow, the relationships between structures and groundwater and the optimum way for watershed management in this subbasin. Geophysical data including, ground magnetic survey and 1D electrical resistivity sounding helped in identifying the lithology and delineating zones of groundwater occurrence. The magnetic data delineated the basement rock, aided in characterizing the geometry of the subsurface structures that control the land surface features and constrain groundwater flow system. The interpreted subsurface structure elements include six sets of faults trending NE-SW, NW-SE, NWW-SEE, NEE-SWW, N-S and E-W. The basement depth was estimated at zero at the southern part and about $5187 \mathrm{~m}$ at the northern part. Two aquifer systems were characterized, the shallow aquifer of the Wata Formation (Upper Cretaceous) and the deep aquifer of the Malha Formation (Lower Cretaceous). The probability of groundwater occurrence increases towards the central part of the study area to north direction, where the thickness of the sedimentary basin reaches its maximum at the center of the study area. Different trends of faults were interpreted from the geoelectrical cross-sections along two transects. Three patterns of faults were characterized including step faults, graben faults and horst faults. These faults could be indicated on the geo-electrical section by a marked difference in the layers' thicknesses. The magnetic data confirmed the locations of the faults delineated by the electrical resistivity profiles. The outlined faults are trending mainly in NE-SW, NW-SE, NWW-SEE, NEE-SWW and E-W directions.

Lineament structures delineation and drainage pattern analysis were evaluated and interpreted from the analysis of remote sensing (RS) data and geographic information system (GIS) technique. The SRTM-DEM (Shuttle Radar Topographic Mission-Digital Elevation Model) was also utilized to automatically identify and extract drainage network. Interpretation and analysis of the inferred lineament structures indicate the presence of a number of main lineament populations that trends: NE-SW, NW-SE, NNW-SSE, NWW-SEE, E-W and N-S. Meanwhile, the interpretation and analysis of drainage pattern network indicate the presence of three main lineament structures that trends: NW-SE, NE-SW and NWW-SEE. Azimuth distribution analysis of both the measured structures and drainage channels shows similar trends, except for very few differences in the prevailing trends. Similarity in orientation of lineament structures, drainage system, and subsurface structural trends were recognized in the area under study. In conclusion, the integration between remote sensing and geophysical data revealed a close matching between the surface structural lineaments and subsurface structural trends could be verified. The preferred conduits of surface run-off and groundwater flow, as well as, the proper locations for groundwater exploitation could be determined.
\end{abstract}

\section{INTRODUCTION}

Naqab desert is located at east central Sinai, Egypt. It is bounded by latitudes $29^{\circ} 30^{\prime}, 30^{\circ} 30^{\prime} \mathrm{N}$ and longitudes $33^{\circ} 20^{\prime}, 34^{\circ} 55^{\prime} \mathrm{E}$ as shown in Figure 1 . The area is covered by crystalline rocks of Precambrian age and sedimentary rocks of Cretaceous and Eocene ages. It is traversed by Suez-Nuweibaa and Naqab- Taba asphaltic roads. The area is drained by wadies running northward to wadi Gerafy and then to the eastern Egyptian border.

The study area is characterized by moderate to high topography with elevation values ranging from $252 \mathrm{~m}$ asl at the northern part, $387-520 \mathrm{~m}$ asl at the northwestern part, and up to $860 \mathrm{~m}$ asl at the southeastern part (Greenwood, 1997). The weather and climate patterns of Sinai are largely dictated by its 
position between the vast land masses of Africa and Asia. Neither the Mediterranean nor the Red Sea significantly ameliorates the continental extremes inherited from its large land neighbors (Greenwood, 1997). Simply, Sinai's weather is very hot and dry. However, there are significant differences between the day and night temperatures. The meteorological data from Nekhel, Ras El-Naqab, Ras Nasrani and Katherina stations during the period 1983-1994 revealed that the maximum recorded air temperature is $35.4{ }^{\circ} \mathrm{C}$, and the minimum is $2.1{ }^{\circ} \mathrm{C}$. The maximum mean evaporation rate was recorded by Nekhel station at $17.5 \mathrm{~mm}$ /day in June, while the minimum value is $4.6 \mathrm{~mm} /$ day at Ras El-Naqab in December.

The mean annual rainfall is generally less than $100 \mathrm{~mm}$. The heavy rainfall during a winter season in Sinai generally occurs between November and January. It ranges from $38.2 \mathrm{~mm}$ at Nekhel station to $52.3 \mathrm{~mm}$ at Ras El Naqab station. The average annual rainfall in wadi Gerafy basin is about $25 \mathrm{~mm}$, while the maximum daily rainfall is $73 \mathrm{~mm}$ (Kamal et al., 1980).

Flash floods occur in several dissecting hydrographic basins every few years causing some hazards to the farms, population and highways. The flash floods occur in Wadi Watir almost every year with water quantity ranging from 3.84 to 31.62 million cubic meters per each flood period (Shabana, 1999). The relative humidity reaches its maximum value $(42.5 \%-67.9 \%)$ in January, while the minimum values $(25.6 \%$ - $48.5 \%)$ were recorded in April as obtained from Ras El Naqab and Nekhel stations, respectively.

Groundwater contributes a significant part of water supplies in Sinai, especially in areas far from surface water channels as the study area. Geophysics has been extensively used for groundwater studies in different conditions (Massoud et al., 2016; Kenawy et al., 2016; Mesbah et al., 2017; Jalem and Singh, 2018; Sholichin and Prayogo, 2019). This study aims at identification, characterization and management of groundwater resources at Naqab watershed area by integrated application of land magnetic, land gravity and electrical resistivity methods.

\section{GEOLOGIC SETTING}

Sinai Peninsula is wedged between the Arabian and African plates. The boundary between them runs east-west from Hammam Faraoun on the Gulf of Suez to Nuweibaa on the Gulf of Aqaba, and coincides with Tih and Egma escarpments in the central part of the peninsula (Greenwood, 1997). The igneous and metamorphic rocks of the Arabian-Nubian shield are exposed in the south. This shield is composed of a series of island-arcs which were created during the Late Proterozoic and Early Paleozoic during the Pan- African orogeny (Gass, 1981). Structurally, the study area has different faults, folds and joints (Steinitz et al., 1978). These faults are intersected at acute angles, commonly about $30^{\circ}$ and $60^{\circ}$ suggesting conjugate shear faults related to the shearing stresses accompanying the development of the Gulf of Suez and Gulf of Aqaba.

According to Shata (1956), Said (1962) and Atalla (1993), the rock units in the study area (Fig. 2) are ranging in age from Precambrian to Quaternary. A brief description of the rock units is given in the following sections.

\subsection{PRECAMBRIAN BASEMENT ROCKS}

The Precambrian rocks form an extensive outcrop at the southeastern part of the area. They are non-conformably overlain by the Lower Cretaceous sandstone (Malha Formation). The Precambrian rocks are differentiated into diorite-gneiss, gabbro-diorite, granosynite, younger granite and alkaline volcanics.

\subsection{CRETACEOUS SUCCESSION}

The area under consideration is largely occupied by limestone and sandstone of Cretaceous age. The succession is thick, well bedded, and gently inclined except in fault zones where it becomes deeply inclined. The Cretaceous succession rests non- conformably on basement rocks at the southeastern parts of the area. It is also faulted against the alkaline volcanics. The succession is reviewed hereafter from bottom to top.

- Malha Formation, of Lower Cretaceous age, consists of fine to coarse-grained, cross-bedded sandstone to argillaceous sandstone with kaolin and clay lenses with an average thickness of about $180 \mathrm{~m}$.

- Galala Formation, of Cenomanian age, consists of hard siliceous, yellowish brown, and cavernous dolomitic limestone with clay and marl inter-beds with a thickness value of about $94 \mathrm{~m}$.

- Wata Formation, of Turonian age, consists of white to grey, massive limestone with yellow marl and grey chert inter-beds with a thickness reaches $97 \mathrm{~m}$.

- Sudr Formation, of Senonian age, is locally exposed and forming the floor of the southern part of wadi Gerafy, while the rest of the formation is unconformably overlain by Plio-Pleistocene terraces. It consists of chalk and chalky limestone, which suggests deposition in calm marine conditions with progressive submergence and having planktonic pack-stone facies.

\subsection{EOCENE SUCCESSION}

The Lower Eocene succession covers the western part of the investigated area, and is represented by Thebes Formation. It is relatively limited and faulted against the limestone of Wata Formation. The succession consists of biostromal limestone with interbeds of chert. 


\subsection{PLIO-PLEISTOCENE TERRACES}

The Plio-Pleistocene terraces exhibit a fan-shaped area that irregularly extends for 10- $20 \mathrm{~km}$ along the foot hills of Cretaceous and basement outcrops. They are lacustrine facies with an average thickness of $10 \mathrm{~m}$ above the wadi floors. The terraces consist mainly of clay, silt, sand, marl and gravel covered by limestone, chert and basement fragments.

\subsection{QUATERNARY DEPOSITS}

The Quaternary deposits are mainly composed of silt, sand, cobbles and gravel, and extend further to north beyond the terraces. They have irregular extension and variable thickness from 2 to $50 \mathrm{~m}$.

\section{METHODS AND RESULTS: \\ 3.1. REMOTE SENSING METHOD AND GIS TECHNIQUE}

In the study area, the remote sensing data and geographic information system technique were used to: delineate and map the lineament structures trends and hydrological parameters (SRTM DEM, Drainage pattern (Stream)) that control the groundwater flow and accumulation in the study area. Two types of remote sensing data have been used: The first type involved LANDSAT Enhance Thematic Mapper $($ ETM+7) images, with spatial resolution of 30 meters for bands 1 to 5 and band 7. The resolution for band 6 (thermal infrared) is 60 meters and resolution for band (8 panchromatic) is 15 meters. The second type involved SRTM (Shuttle Radar Topographic Mission), DEM (Digital Elevation Model) with $30 \mathrm{~m}$ spatial resolution.

The remote sensing data was analyzed and interpreted using (ENVI v. 4.3) and (ARC MAP v. 10.3) software's package for preparing thematic layers (lineament structures and hydrological parameters). This study used standard tools of image processing including (ENVI v.4.3) program for digital processing of the satellite data. The digital image processing techniques that were applied are: color composite images, Band rationing, Principle component analysis and Enhance image linear $2 \%$ and Image equalization. Having applied the last processing steps on remote sensing data, then the data will be transferred into ARC MAP program to extract the lineament structures and hydrogeological parameters.

\subsubsection{STRUCTURE LINEAMENT MAP:}

A lineament is any extensive linear surface on a planet, as a fault line or fracture line. Lineaments like joints, fractures and faults may provide the pathways for groundwater movement. In the study area, the lineament structures were extracted manually on (ARC MAP 10.3 v.) program after applying the following processing steps using (ENVI 4.3 v.) program: (1-False color composite to bands $(123,324$, 432, 531, 541, 543, 741 and 742 ) in RGB, 2- Band ratioing to bands $(5 / 7,2 / 3,4 / 5)$ in $R G B, 3$ - Principle component analysis (PCA) to bands (123, 234 and 547 ) in RGB, 4- Enhancement linear image $2 \%$ to bands (471, 531, 541 and 742) in RGB and 5- Enhancement equalization to bands (543 and 741) in RGB).

The output images from the last processing steps were fed into (ARC MAP $10.3 \mathrm{v}$.) to extract the lineament structures manually as show in Figure 3. The Figure 3 represents the lineament structures map with (faults, fractures and contacts). The close examination of the lineament structures map shows that: the (NE-SW, NW-SE, NNW-SSE, NWW-SEE, $\mathrm{E}-\mathrm{W}$ and $\mathrm{N}-\mathrm{S}$ ) trends are represented in these maps arranged in decreasing order of magnitude. These trends are related to nearsurface and deep lineament structures in the prospect area of study, which play an important role in detection the direction of the movement and accumulation of surface water bodies and then the ground water at the subsurface.

\subsubsection{SRTM DEM MAP}

The visual inspection of the SRTM DEM map (Fig. 4) shows that; the study area were classified into two parts according to elevation: the first part represents high elevation values (1062) with brown color, this highly elevation area located in north, south and south-east directions. Meanwhile, the second part represents low elevation values (0) with pink color which are located in north-west, north-east and southeast directions. The following processing techniques were applied on the SRTM DEM using (ARC MAP $10.3 \mathrm{v}$.) program to get the parameter of hydrology.

In the area under investigation, the SRTM DEM model required, first, that all the sinks (i.e. local depressions) to be filled and raised in elevation to their neighbouring cells in order to ensure the flow continuity within the catchment to an outlet (Jenson and Dominique, 1988).

In the present study, after the SRTM DEM was filled, the flow direction of each cell into the lowest elevation cell of the surrounding eight cells was determined using (ARC MAP 10.3 v.) program. Once the route of flow was determined for each cell in the DEM.

In the study area, after flow direction was determined, it is possible to accumulate the number of upslope flow contributing cells (i.e. areas) and the flow paths of each cell using (ARC MAP 10.3 v.) program. After applying the last processing techniques on SRTM DEM data using (ARC MAP 10.3 v.) program, the drainage pattern map was created.

\subsubsection{DRAINAGE PATTERN MAP:}

Drainage pattern is one of the most important indicators of hydrogeological features, because drainage pattern and density are controlled fundamentaly by the underlying lithology. In the study area, by using the (ARC MAP $10.3 \mathrm{v}$.) program it is possible to delineate the drainage pattern map with orders as shown in Figure 5. The close examination of 


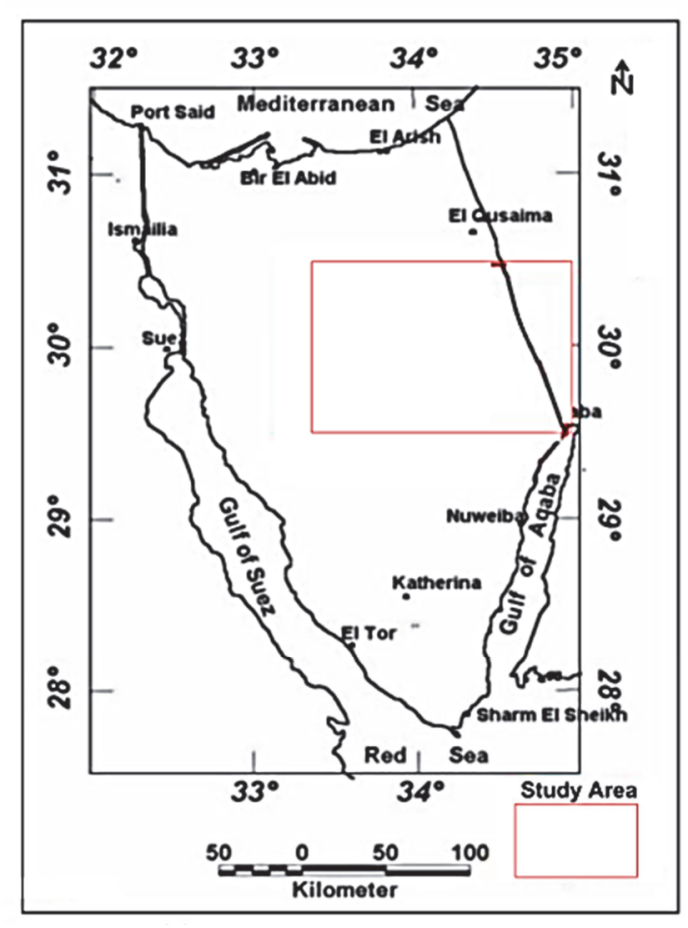

Fig. 1 Location map of wadi Gerafy study area, Naqab desert, East central Sinai, Egypt.

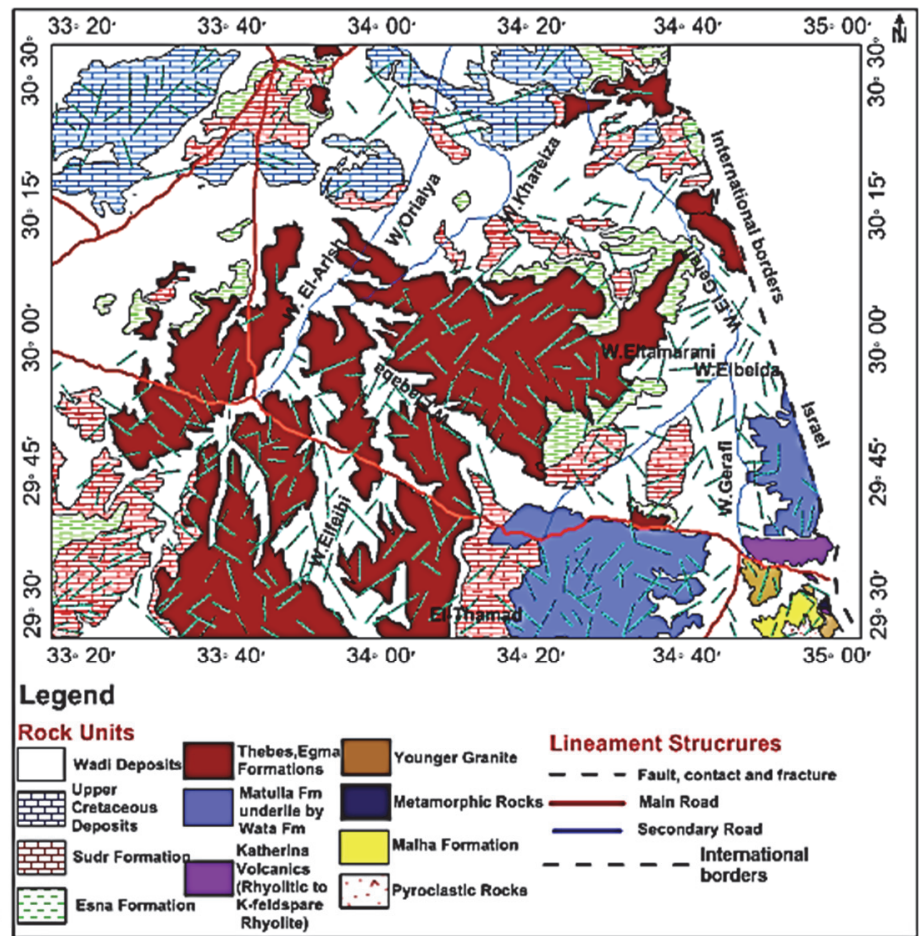

Fig. 2 Geologic map of the study area (modified after CONOCO, 1983).

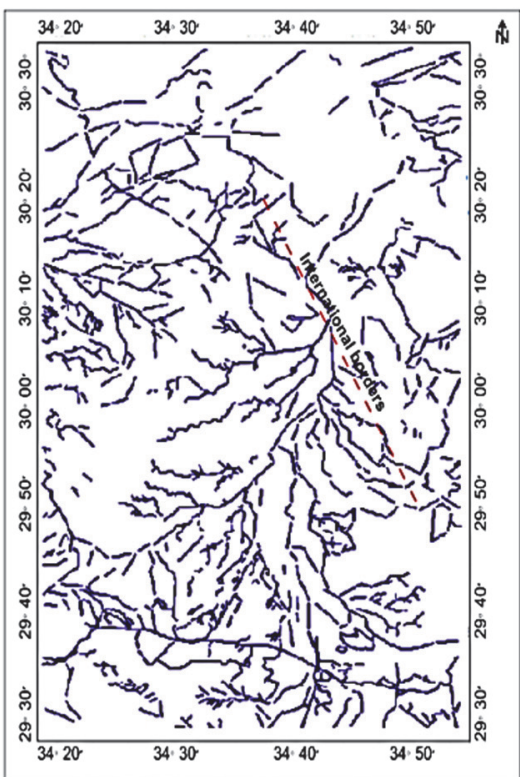

Fig. 3 Structure lineament map (fault, fracture and contact) deduced from processed remote sensing data to study area.

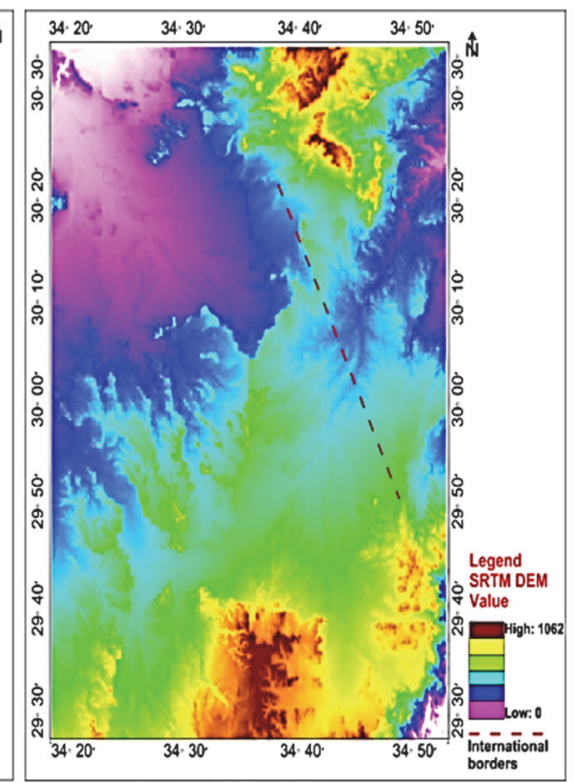

Fig. 4 SRTM DEM (shuttle radar topographic mission digital elevation model) map of the study area.

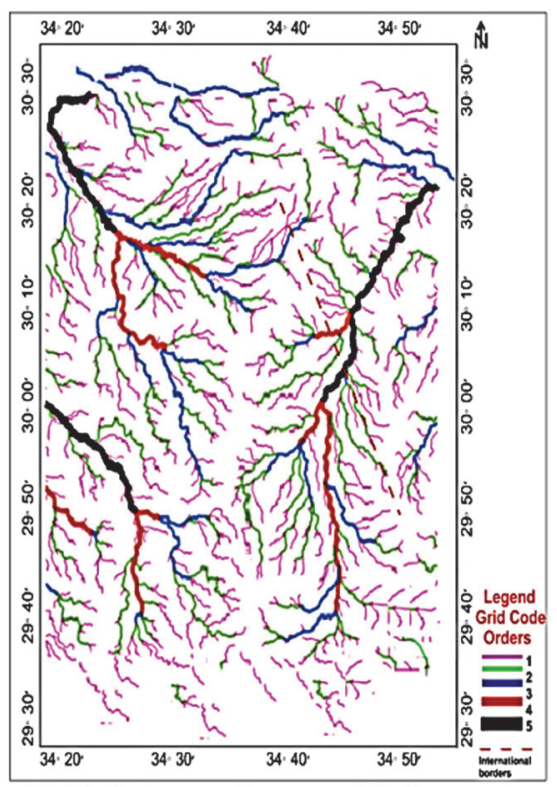

Fig. 5 Drainage pattern map with orders of the study area. drainage pattern map shows that: there are five line types which have black, red, blue, green and violet colors respectively, where the black line type represents the main order and is called high drainage density. Meanwhile, (the red, blue, green and violet line types) are called medium and low drainage density.
There are three drainage pattern systems according to these five line types which are located at (north-east, north-west and south-west) directions and then the surface water bodies are gradually gathered and accumulate starting from violet to black colors. The drainage pattern types in the prospected area belong to (annular and radial), which are strongly 
influenced by geological structures. According to the drainage types in the study area, the structural lineaments have (NW-SE, NE-SW and NWW-SEE) directions. These trends play an important role in movement and accumulation of surface water bodies and subsurface ground water.

\subsection{GROUND MAGNETIC DATA}

In this study, magnetic data were utilized for estimation of the structural framework beneath the surface of the area, the depth to the upper surface of the basement rocks to determine the thickness of sedimentary cover. The magnetic method data was obtained after digitizing the coordinate of the study area from the ground total magnetic intensity map of Sinai (scale 1:500000), (EGSMA, 2003). After the data collection, the processing techniques described below were applied to the magnetic data, and then the qualitative and quantitative interpretations of the magnetic data were done.

The qualitative techniques are based on the examination of (total intensity magnetic map, reduction to the north of magnetic pole (RTP), first vertical derivative map (FVD), horizontal gradient map (HG), analytical signal map (AS) and tilt derivative map (TDR) and visualize the most characteristic features of the magnetic bodies from the pattern and values of the contour lines of these maps. After studying these lateral maps the structural framework of the area is clearly defined. Meanwhile, the quantitative interpretation of magnetic data is based on fault delineation using Euler deconvolution (ED) and source edge detection (SED) techniques and depth to the surface of the basement rocks and define the sedimentary basin using the 2D-magnetic modeling (GM-SYS program, v. 8.3).

\subsubsection{TOTAL INTENSITY MAGNETIC MAP (TIM)}

The magnetic data set was obtained by digitizing the total intensity magnetic map of Sinai (EGSMA, 2003). After applying the necessary corrections, the data were gridded and contoured to create the total intensity magnetic map (Fig. 6). The total intensity magnetic map can be divided into two zones: The first zone represents the low magnetic field, which lie in the NWW-SEE, N-E and N-W directions and central part of the study area. The value of magnetic field of this zone range from $42107.9 \mathrm{nT}$ to $42246 \mathrm{nT}$. Meanwhile, the second zone represent the high magnetic field, which lie in the ENE, SSE and SWS directions and generally lower part of the study area. The value of magnetic field of this zone range from $42259.4 \mathrm{nT}$ to $42460.1 \mathrm{nT}$.

\subsubsection{REDUCTION TO THE NORTH OF MAGNETIC POLE MAP (RTP)}

Before going to further analysis of magnetic data, the data underwent systematic processing steps started by converting the TIM data from space domain to frequency domain using Fast Fourier Transform (FFT). Then the converted data were filtered in order to remove the dipolar effects of the total magnetic field of the Earth and to produce the reduced- to the-north magnetic pole map (RTP), using inclination and declination values of $44.7^{\circ}$ and $3.8^{\circ}$, respectively (Fig. 7).

Inspection of the RTP map revealed two major magnetic anomalous zones. The first zone occupies the northern part of the study area and branched into $\mathrm{NE}$ and NW trending zones. It represents the low magnetic field related to Plio-Pleistocene Terraces where the magnetic field intensity was ranging from $42071 \mathrm{nT}$ to $42287 \mathrm{nT}$. Meanwhile, the second zone occupies the southern part of the area and represents the high magnetic field values related to Precambrian basement rocks. The magnetic field intensity of this zone ranges from $42307 \mathrm{nT}$ to $42531 \mathrm{nT}$.

\subsubsection{FIRST VERTICAL DERIVATIVE MAP (FVD)}

First vertical derivative of the total-field magnetic anomaly usually accentuates gradients along edges of shallow magnetic sources. Comparison of the first vertical derivative map (Fig. 8), with the total intensity magnetic map (Fig. 6), shows a marked increase in 'visibility' of structural features at the contact (zero contour line) between high anomalies zone (red to pink colors) and low anomalies zone (green to blue colors), especially in the NE-SW, NW- SE, E-W, N-S and NWW-SEE directions. These structure elements are located between Precambrian basement rocks and the surrounding sedimentary rocks of the study area.

\subsubsection{TILT DERIVATIVE MAP (TDR)}

The TDR analysis shows the geologic features like faults which are depicted as magnetic lineaments. This method facilitates the horizontal location with extent of edges of anomalous sources assuming vertical contact model. It is suggested that the zero contour line (the black line) in the TDR map (Fig. 9) is the location of abrupt changes in magnetic susceptibilities between positive and negative anomalies that is particularly present at sharp gradients.

The zero contour line represents the contact boundary of magnetic sources and shows the contact locations. Zero contours can be identified as black color which is separating the green color (negative values) and red colors (positive values) can be seen from the color scale bar. On the other hand, positive values are assumed to be located directly above these magnetic sources while negative values are located away from them. When comparing between the (RTP) map (Fig. 7) with the TDR (Fig. 9) map there is a significant increase in structure features, especially in the NE-SW, NW-SE, NWW-SEE, E-W and N-S directions.

\subsubsection{ANALYTICAL SIGNAL MAP (AS)}

Analytic signal reduces magnetic data to anomalies whose maxima mark the edges of magnetized bodies and whose shape can be used to 

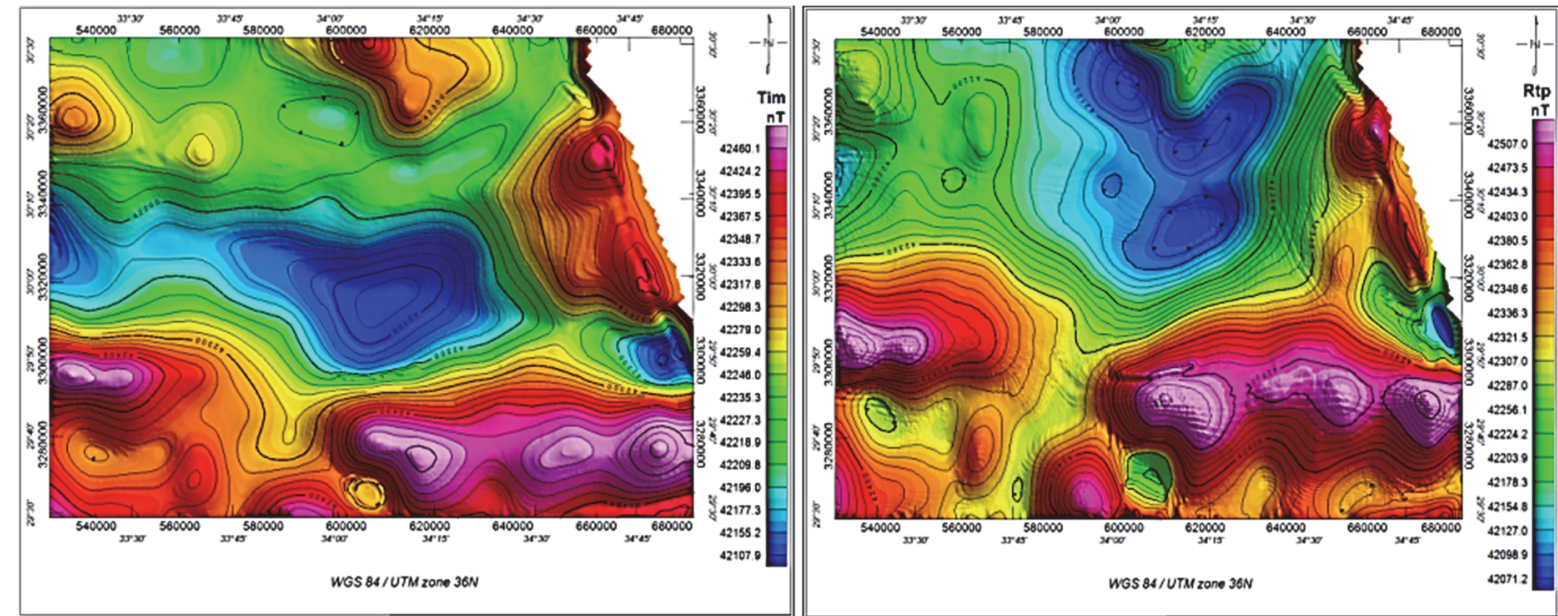

Fig. 6 Total Intensity Magnetic Map of Wadi Gerafy Prospected Fig. 7 The reduction to the northeren of magnetic pole (RTP) map Area, Naqab desert, East Central Sinai, Egypt. of the study area.

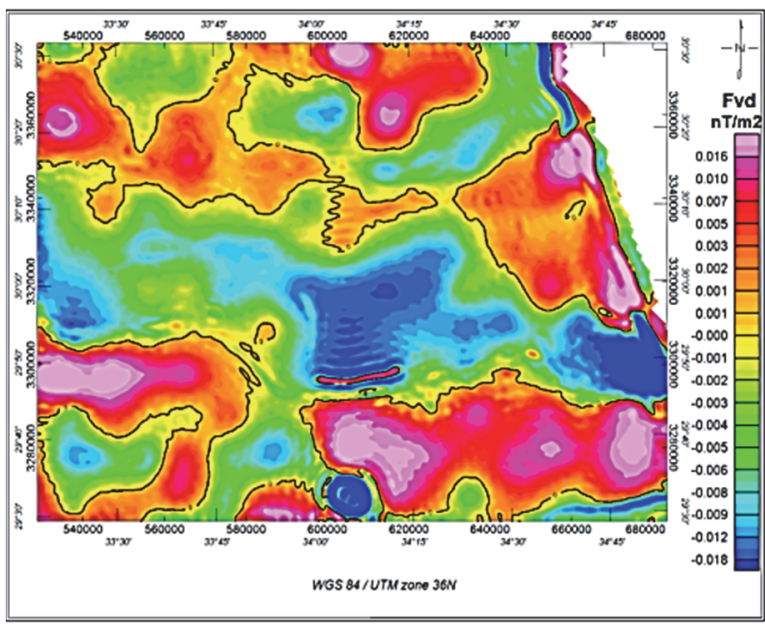

Fig. 8 First vertical derivative of the total intensity magnetic map of the study area.

determine the depth of these edges, so that the close examinations of the AS of the TIM map (Fig. 10) shows that, the NE-SW, NW-SE, NWW-SEE, N-S and $\mathrm{E}-\mathrm{W}$ directions have a great number of maxima that are observed as large to medium closures (red to pink colors). These maxima emphasize the faults and/or the contacts between Precambrian basement rocks and the surrounding sedimentary rocks of the study area, also these maxima can be used to locate the outlines of magnetic sources in the study area, which is shown by the higher analytic signal value $(0.010 \mathrm{nT} / \mathrm{m}$ to $0.027 \mathrm{nT} / \mathrm{m})$.

\subsubsection{HORIZONTAL GRADIENT MAP (HG)}

This map delineates the vertical and lateral location of the shallow and deep subsurface causative sources. Comparison of the horizontal gradient map (Fig. 11), with the total intensity magnetic map (Fig. 6), shows a marked increase in 'visibility' of structural features, especially in the NE-SW and NWW-SEE trends. The most conspicuous horizontal gradient (HG) anomalies are the three large high

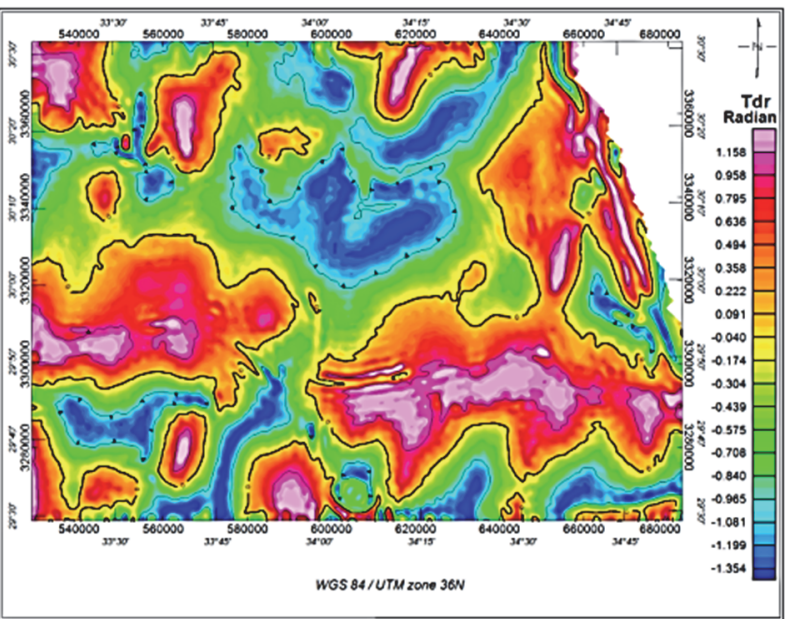

Fig. 9 Tilt derivative map of the study area. The black zero contour line demonstrates the edge of the contact and localizes the contact location. The white contour lines are equal to $\pm 45^{\circ}$ and can be used for calculating depth on edges.

elongate positive $\mathrm{HG}$ anomalies that nearly occupy the nearly central and extreme north- east, south- east and south-west corner parts of the study area. The elongations of the contour lines for the HG anomalies with irregular pattern and their gradients that separate the high $\mathrm{HG}$ area from the low $\mathrm{HG}$ area indicate that it is structurally-controlled by a number of faults having major axes in NE-SW, NWW-SEE, N-S and E-W directions.

\subsubsection{EULER DECONVOLUTION MAP (ED)}

Through the application of Euler deconvolution with $\mathrm{SI}=0.0$, a Euler map (Fig. 12) was derived which shows clustering of circles in linear and curved shapes indicating the nature of probable contacts between the rock units as shown in the interpreted lineament map (Fig. 13). The linear clustering circles are suggested to be the result of faults and or contacts with depths values ranging between $(-527 \mathrm{~m}$ and $>2250 \mathrm{~m})$. The solutions of depths $(-527 \mathrm{~m}$ to $-348 \mathrm{~m})$ are representing the shallow depths. These solutions take in NE-SW, NW-SE and NWW-SEE directions. Meanwhile, the 


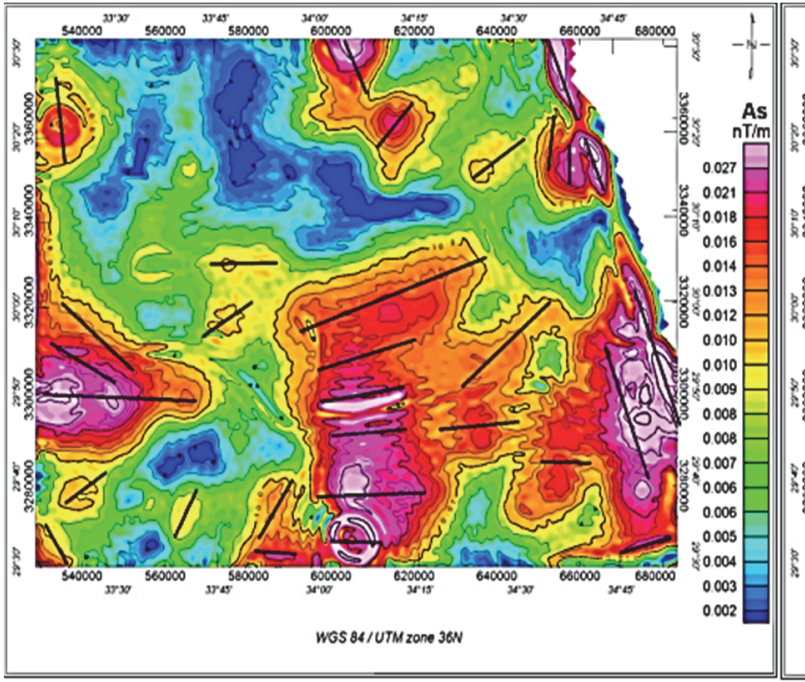

Fig. 10 Analytic signal map of the study area, which illustrate the maxima boundary and contacts between diferent anomalies.

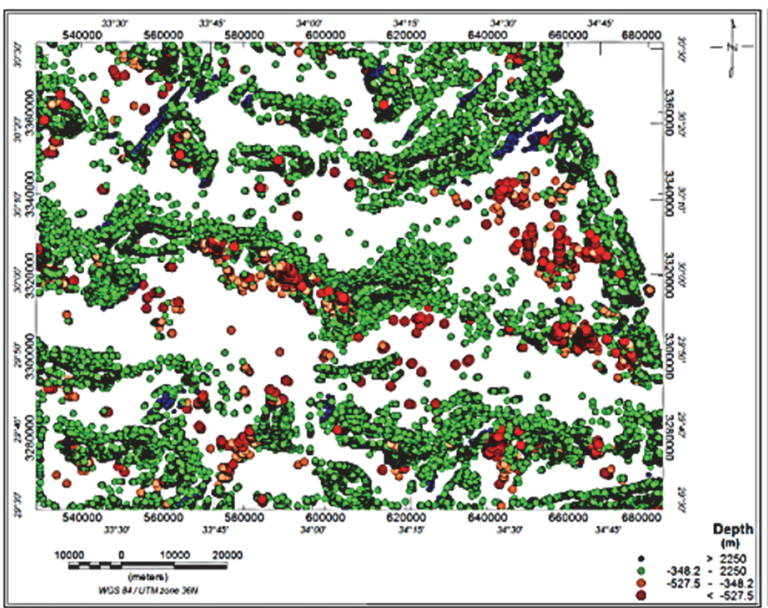

Fig. 12 Euler deconvolution map show Fault pattern at different depths interpreted from the total intensity magnetic map of the study area, using Euler deconvolution techniques (S.I.=0), which the blue circles related to deep lineament structures and red circles related to shallow lineament structures.

solutions of depths $(-348 \mathrm{~m}$ to $>2250 \mathrm{~m})$ are representing the deep depths, which widely spread along the study area and also have taking the NE-SW, NW-SE and NWW-SEE directions. After the visual inspection to the Euler deconvolution map and interpreted lineament map, It can deduce the main lineaments of the contacts and faults trends which have taking the (NE-SW, NW-SE, NWW-SEE, N-S and $\mathrm{E}-\mathrm{W}$ directions.

\subsubsection{SOURCE EDGE DETECTION MAP (SED).}

The source edge detection of the horizontal gradient of the magnetic data was calculated using (GEOSOFT, 2014). The close examination of the source edge detection map (Fig. 14) and rose diagram to source edge detection (Fig. 15) shows that: the main trends of the edges (i.e. geological contacts), geologic boundaries and peaks produced from horizontal

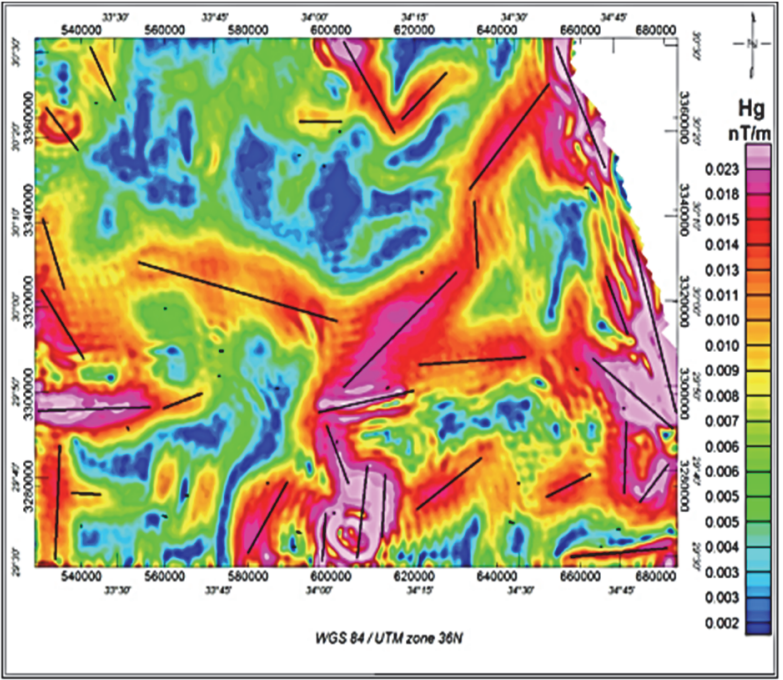

Fig. 11 Horizontal gradient (HG) map of the study area, which illustrate the structure faults and lineaments affected between anomalies.

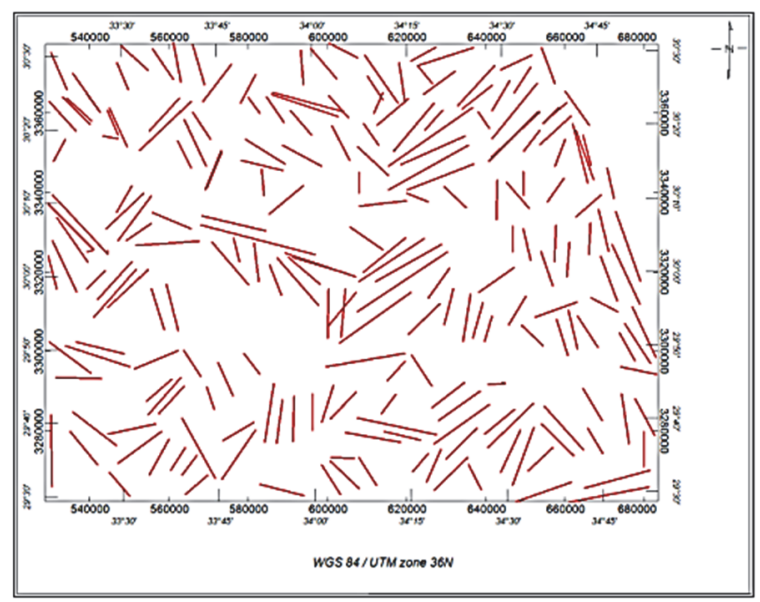

Fig. 13 Interpreted lineament map, deduced from euler deconvolution technique.

gradient are: NE-SW and NEE-SWW and the other trend are: NW-SE, NWW-SEE, N-S and E-W directions.

\subsubsection{D MAGNETIC MODELING}

To outline the basement relief, estimate the depth to the upper surface of the basement and in turn to determine the thickness of sedimentary section, 2D magnetic modeling was carried out along two N-S trending profiles (AA- and BB-) using Geo soft (2014) software. Locations of the magnetic profiles (Fig. 16) were selected in the watershed zone to be at the same locations in which the electrical resistivity measurements have been conducted. Figure 17 shows the $2 \mathrm{D}$ model profile AA- obtained from magnetic data modeling.

The modeled profiles AA- and BB- show best fit between the observed and calculated data with 


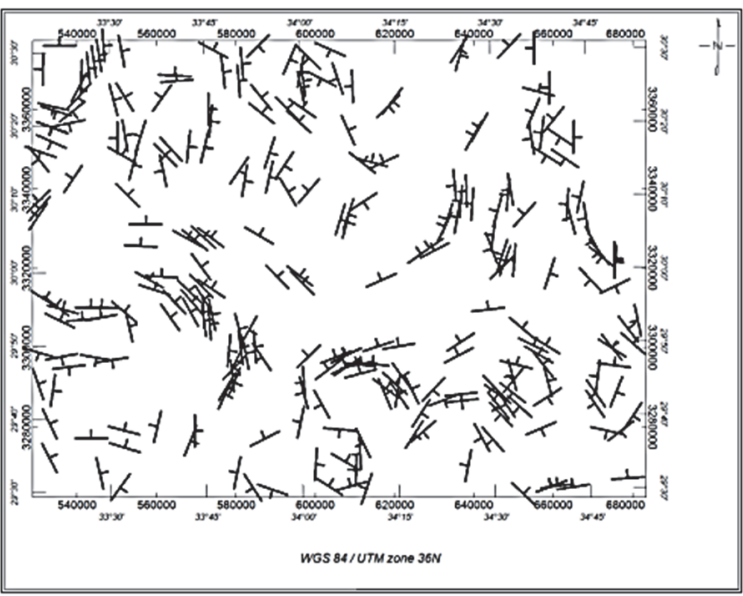

Fig. 14 Source edge detection map of the horizontal gradient of magnetic data of the study area.

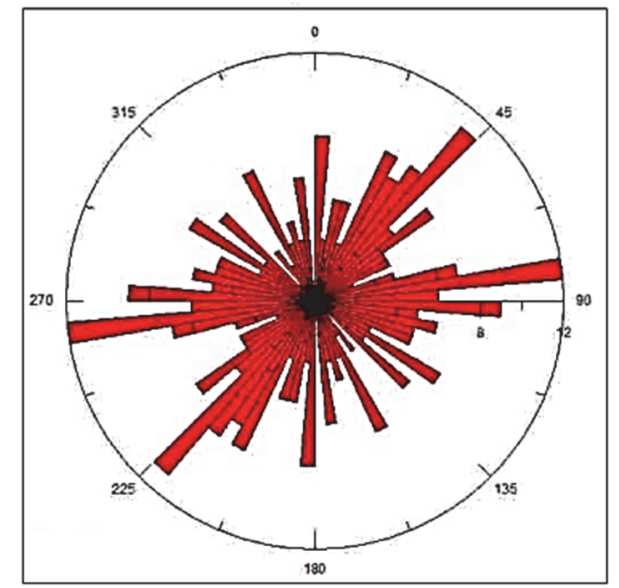

Fig. 15 Rose diagram showing the edges and geologic boundaries resulted from source edge detection map of the horizontal gradient of total intensity magnetic data.

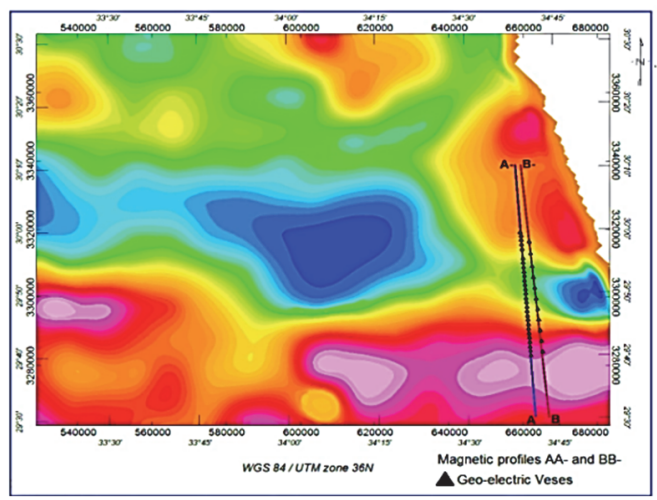

Fig. 16 location of the magnetic profiles AA-, BB- and geoelectric Veses along the study area.

s

\section{N}

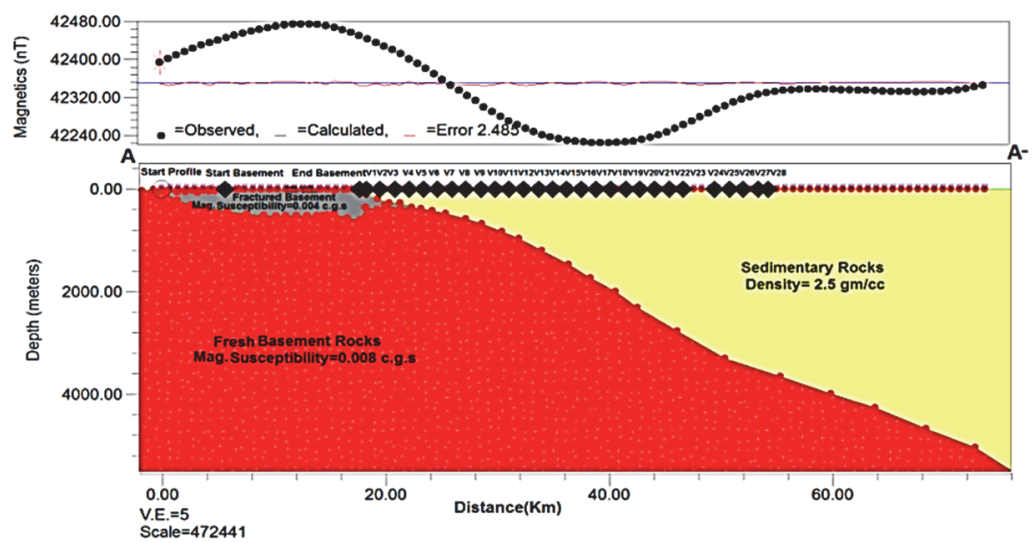

Fig. 17 Two-Dimensional (2D) modelled of magnetic profile AA-,wadi Gerafy area, Naqab desert, East Central Sinai, Egypt.

miss- fit errors of 2.485 and 2.398 , respectively. The magnetic susceptibility values of 0.004 and 0.008 c.g.s. were assumed in these models for fractured basement and fresh basement, respectively. Also, a density value of $2.5 \mathrm{gm} / \mathrm{cc}$ was assumed for sedimentary rocks.
EXAMINATION OF PROFILES AA- AND BB-REVEALED THE FOLLOWING FEATURES:

- The basement rocks are exposed on the ground surface at the southern part of the study area and deepen towards the north. 
- The upper surface of basement was detected at $5187 \mathrm{~m}$ b.g.s at the northern part of profile A-A and $4391 \mathrm{~m} \mathrm{b.g.s}$ at the northern part of profile B-B'.

- There is a gradual increase in the depth of basement rocks from south to north along the digitized profiles.

- There is roughly elliptical basin extending from the central part of the study area towards the north, which is in a good agreement with the surface geologic lineaments.

- Uplifting of the basement rocks at the southern part and subsidence at the northern part could be attributed to faulting effect.

\subsection{ELECTRICAL RESISTIVITY DATA}

\subsubsection{RESISTIVITY DATA ACQUISITION}

The electrical resistivity data were measured in the form of vertical electrical sounding (VES) at 39 points arranged along two north-south trending profiles (Profile-P1 and Profile-P2) in the watershed zone of the study area. The profile-P1 was covered by 28 measuring points (VES-01 to VES-28), while Profile $-\mathrm{P} 2$ was covered by 11 measuring points (VES-29- to VES-39). The VES data were measured by a Russian device - AE-72 applying the standard Schlumberger electrode array with half-current electrode spacing $(\mathrm{AB} / 2)$ varying logarithmically from 1 to $4000 \mathrm{~m}$. Locations of the electrical resistivity measuring points and profiles (Fig. 18) were selected to be at the same locations of the modeled magnetic profiles for better correlation of the basement depth from the two data sets. The measuring points were spaced at about 1-3 km along the selected profiles according to the site accessibility.

\subsubsection{DATA ANALYSIS}

The measured resistivity data were corrected by applying the following steps:

$\checkmark$ Controlling the data values, the sharp peaks or any violation with respect of the general resistivity trend, and

$\checkmark$ Smoothing of the field data curve during data acquisition by single point correction and/or data averaging. After carrying out the necessary processing steps, the plotted data points defined the sounding curve which was used for further analysis.

In this study, both curve matching and analytical procedures were used to identify the presence of resistivity layering (e.g. vertical, horizontal or dipping beds). The curve matching was done manually by using the two-layer curves and auxiliary graphs modified by Orellana and Mooney (1966). This technique is based on partial matching of successive segments of the sounding curves. The process is repeated as many times as required to fit the field curves. Then, geoelectrical parameters of subsurface layers could be determined. The obtained results of the manual modeling were used as initial models for the analytical (computer-based) modeling process.

As for analytical modeling, the computer program IPI 2WIN 1-D (2008), based on a least-squares algorithm, was used to calculate the final earth resistivity model. The justification of the final model was controlled by calculating the Root-Mean-Square error (RMS-error) between the measured and calculated resistivity values. Figure 19 shows a selected example of the obtained geoelectrical models along the profile No.1 in the study area.

\subsubsection{GEOELECTRICAL CROSS-SECTIONS}

The obtained 1D models were used for the construction of two geoelectrical 2D stitched cross sections along Profile-P1 and Profile-P2. Locations of these profiles are shown in Figure 18. The geoelectrical section constructed along Profile-P1 is shown in Figures 20.

Inspection of the 1D models and 2D cross- sections revealed 6 to 9 geoelectrical layers. After correlation of the identified layers with geologic and borehole information (Fig. 21), the geoelectrical layers could be grouped into five geologic units.

The first (uppermost) unit is represented by Wadi deposits of Quaternary age which are composed of silt, sand, cobbles and gravels. Its electrical resistivity ranges between 12.8 and $9163 \mathrm{ohm}-\mathrm{m}$. The second unit is represented by Wata Formation of Turonian age which is composed of fractured limestone with marl and chert inter-beds, with low electrical resistivity values ranges from 0.801 to $257 \mathrm{ohm}-\mathrm{m}$. The third unit is represented by Galala Formation of Cenomanian age which is composed of cavernous dolomitic limestone with clay and marl inter-beds, with electrical resistivity values ranges from 143 to $1371 \mathrm{ohm}-\mathrm{m}$. The fourth unit is represented by Malha Formation of Lower Cretaceous age which consists of fine to coarse-grained, cross-bedded sandstone with kaolin and clay lenses. The electrical resistivity of this formation is low, ranges between 3.67 and $458 \mathrm{ohm}-\mathrm{m}$. The fifth (deepest) unit is represented by the basement rocks of Precambrian age, with electrical resistivity ranges from 162 to $2645 \mathrm{ohm}-\mathrm{m}$.

It is worth to notice that the two boreholes shown in Figure 21) are close to each other. The location of these well shown in Figure 18. However, some rock units such as Sudr and Matulla Formations are missed in El Themed well. Moreover, the depth of Malha Formation was detected at about $480 \mathrm{~m}$ in El Themed well and $640 \mathrm{~m}$ in El Themed 5 well. This lithologic and depth variations could be attributed to faulting effect.

Two aquifer systems were identified in this area. The shallow aquifer is represented by the second geoelectrical layer which is composed of fractured limestone (Wata Formation) of Turonian age (Upper Cretaceous). The deep aquifer is represented by the fourth geoelectrical layer that consists of Nubian sandstone deposits of Lower Cretaceous age. 

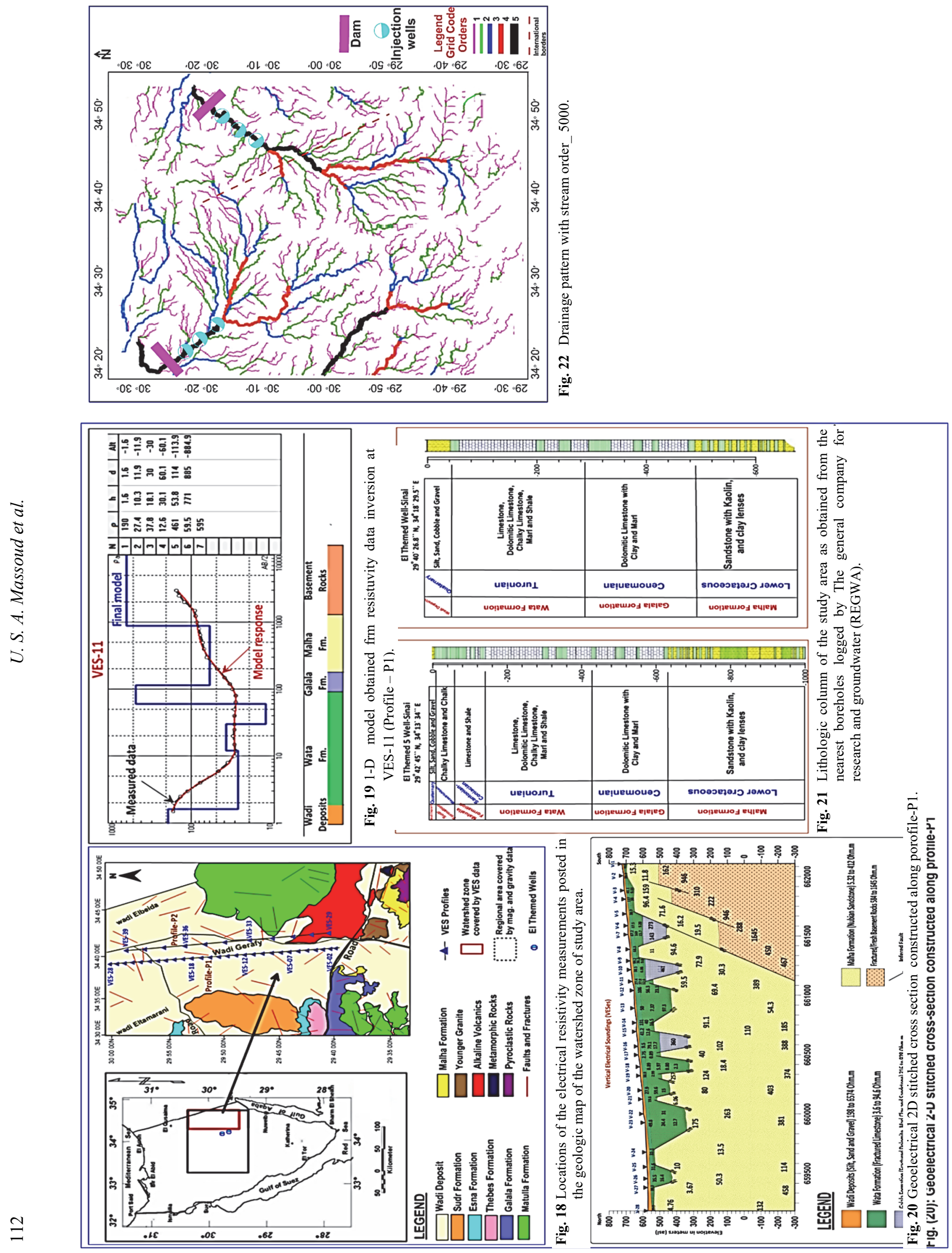
The investigated section is dissected by a set of faults with three fault patterns including step faults, graben and horst shapes. These faults could be indicated on the geoelectrical section by a marked difference in the layers` thicknesses. Moreover, these faults were confirmed by the gravity results. The outlined faults are trending mainly in NE-SW, NW- SE, NWW-SEE and E-W directions.

\section{RESULTS AND DISCUSSION}

The results obtained from remote sensing, magnetic and electrical resistivity and remote sensing could be summarized in the following sections. The remote sensing data and geographic information system techniques were used to delineate and map the lineament structures trends and hydrological parameters (Drainage pattern (Stream)) that control the groundwater flow, movement and accumulation in the study area.

The results of analyzed and interpreted remote sensing data and geographic information system techniques in the study area reveal that: according to the lineament structure map, the surface structures trends are having (NE-SW, NW-SE, NNW-SSE, NWW-SEE, E-W and N-S) directions. Also, according to the Drainage pattern (Streams) map, the drainage types are (annular and radial), which are strongly influenced by geological structures; so that, the surface structures trends have (NW-SE, NE-SW and NWW-SEE) directions.

The magnetic data were analyzed to depict the structure framework beneath the surface, the depth of basement relief and to determine the thickness of sedimentary section. 2D magnetic modeling was carried out along two S-N trending profiles (AA- and BB-) shown in Figure 17. The results revealed that the basement rocks are exposed on the ground surface at the southern part of the study area and deepen towards the north, where the depth to basement was estimated at $5187 \mathrm{~m} \mathrm{b.g.s} \mathrm{(profile} \mathrm{AA-)} \mathrm{and} \mathrm{at} 4391 \mathrm{~m} \mathrm{b.g.s}$ (profile BB-) in the northern part of the area. Accordingly, the thickness of sedimentary section is increased towards the north.

According to the qualitative and quantitative interpretations of magnetic data, the results of the subsurface structure elements reveal that: there are six sets of faults with respect to their trends. These trends are NE-SW, NW-SE, NWW-SEE, NEE-SWW, N-S and E-W directions. These directions of subsurface structures help us in detection the movement and accumulation of ground water in the area under investigation.

The VES data were analyzed and the obtained 1- D models were used for construction of two geoelectrical 2D stitched cross sections along ProfileP1 and Profile-P2 (Fig. 20). Inspection of the 1D models and 2D cross-sections revealed 6 to 9 geoelectrical layers which could be correlated with borehole information and be grouped into five geologic units. The second and fourth geoelectrical layers are of special interest as they represent the shallow and deep groundwater aquifers, respectively.

The shallow aquifer shows different resistivity values varying from 0.8 to $257 \mathrm{ohm}-\mathrm{m}$ and exhibits variable thickness values ranging from 25 to $250 \mathrm{~m}$. Occurrence of groundwater in this aquifer is localized and restricted to the fractured zones. The low resistivity values within this layer provide good indications about the water-filled fractures. So, the low resistivity zones are proper locations for groundwater exploitation from this aquifer. The deep aquifer shows resistivity values ranging from 3.7 to $458 \mathrm{ohm}-\mathrm{m}$ and exhibits thickness values varying from 25 to $850 \mathrm{~m}$. The Nubian sandstone formation is the main deep groundwater reservoir in Sinai. The layer is composed of sandstone with clay lenses. This aquifer is fully water-saturated. Then, the most proper locations for groundwater exploitation from this aquifer are those exhibiting higher resistivity values as they are expected to contain good water quality and low clay content.

\section{CONCLUSIONS AND RECOMMENDATIONS}

Multiple geophysical data sets including land magnetic and electrical resistivity data and remote sensing data were analyzed to characterize and manage groundwater resources and structural controls at Naqab watershed area, east central Sinai, Egypt. The fore-mentioned methods were integrated to achieve the objectives of this study, where magnetic data were used to estimate structure framework, the depth to basement and to determine the thickness of sedimentary section. The electrical resistivity method was employed to characterize the water-bearing formations and their areal extensions. Meanwhile, the remote sensing data was used to delineate and mapping the structure lineaments and drainage pattern systems. This study has successfully revealed two aquifer systems in the study area;

The shallow aquifer is represented by fractured limestone of Turonian age (Wata Formation). The deep aquifer is represented by Nubian sandstone deposits of Lower Cretaceous age. The water-bearing layers are thick enough to store adequate quantities of water to be economically exploited. The maximum thickness of the sedimentary section was attained at the northern part of the study area, where its geometry has been determined by the underlying basement relief. The basement rocks were exposed on the ground surface at the southern part of the study area and deepen northward where the maximum depth to basement was estimated at about $5000 \mathrm{~m}$ b.g.s at the northern part. The sedimentary section was dissected by three fault sets trending in NE-SW, NW-SE, NWW-SEE and E-W directions. The subsurface structural features were matched with the outlined surface lineaments. Then, surface run-off and groundwater flow paths are structurally controlled where they flow along the fault planes from the southern and central parts of the study area towards the 
northeastern and northwestern corners. Analysis of drainage basins shows that the main streams are located at the northeastern and northwestern corners of the study area as indicated by the black line order in Figure 5. For better exploitation of groundwater, two dams are to be constructed at these locations (one dam for each location) as indicated by the pink rectangles in Figure 5 to avoid excessive surface runoff to be drained away during the rainy season. Then, three injection wells should be drilled along the major drainage course of each basin to inject and store excessive surface water into subsurface aquifers to be used during dry seasons.

\section{REFERENCES}

Atalla, R.F.: 1993, Geology of Naqab area, east central Sinai Peninsula, Egypt. Internal Report, Geological Survey of Egypt, $18 \mathrm{pp}$.

EGSMA: 2003, Bouguer anomaly map and total intensity magnetic map of Sinai-Egypt. Egyptian Geological Survey and Mining Authority, Internal Report No. 21.

Gass, I.G.: 1981, Chapetr 15 Pan-African (Upper Proterozoic) plate tectonics of the Arabian- Nubian Shield. Developments in Precambrian Geology, Elsevier, 387-405. DOI: $10.1016 / \mathrm{S} 0166-2635(08) 70020-3$

GEOSOFT: 2014, Oasis Montaj Data Processing anc Analysis (DPA) System for Earth Science Applications: ver. 8.3. Toronto, Ontario. Geosoft Inc.

Greenwood, N.H.: 1997, The Sinai: A Physical Geography. University of Texas Press.

IPI2WIN Software: 2008, A package for automatic anc interactive semi-automatic interpretation of VES and IF data. Moscow State University, Geological Faculty: Department of Geophysics.

Jalem, K. and Singh, S.K.: 2018, Water harvesting through inter-basin transfer technique for part of Visakhapatnam urban area using geo-spatial technology. Environ. We Int. J. Sci. Tech., 13, 79-91.

Jenson, S. and Domingue, J.: 1988, Extracting topographic structure from digital elevation data for geographic information-system analysis. Photogramm. Eng. Remote Sens., 54, 11, 1593-1600.

Kamal, F.S., EL-Shamy, I.Z. and Swedan, A.S.: 1980 . Quantitative analysis of the geomorphology anc hydrology of Sinai Peninsula. 5th Conference of Africar Geology, Cairo, Egypt, 319-332.
Kenawy, A.A., Massoud, U., Ragab, E.A. and El-Kosery, H.M.: 2016, Investigation of the probable wastewater infiltration and its impact on groundwater quality by electrical resistivity tomography and hydrochemistry: a case study of the Pleistocene aquifer at El Sadat city, Egypt. Environ. Earth Sci., 75, 194. DOI: $10.1007 / \mathrm{s} 12665-015-5001-7$

Massoud, U., Khalil, M.M., Tokunaga, T. and Santos, F.A.M.: 2016, Preliminary hydrogeophysical investigation at the 10th of Ramadan City, Egypt, by 1D and 2D inversion of VES data. Near Surf. Geophys., 14, 3, 287-297. DOI: 10.3997/1873-0604.2016005

Mesbah, H.S., Ismail, A., Taha, A.I., Massoud, U. and Soilman, M.M.: 2017, Electrical and electromagnetic surveys to locate possible causes of water seepage to ground surface at a quarry open pit near Helwan city, Egypt. Arab. J. Geosci., 10, 230. DOI: $10.1007 / \mathrm{s} 12517-017-2997-\mathrm{x}$

Orellana, E. and Mooney, H.M.: 1966, Master tables anc curves for vertical electrical soundings over layerec structures. Interciencia, Madrid, 34.

Rabeh, T., Ali, K., Bedair, S., Sadik, M.A., Ismail, A.: 2019. Exploration and evaluation of potential groundwates aquifers and subsurface structures at Beni Suef area ir southern Egypt. J. Afr. Earth Sci., 151, 9-17. DOI: $10.1016 /$ j.jafrearsci.2018.11.025

Said, R.: 1962, The Geology of Egypt. Elsevier Publishing Company, Amsterdam, $337 \mathrm{pp}$.

Shabana, A.R.: 1999, Geology of water resources in some catchment areas draining in the Gulf of Aqaba, Sinai. Egypt: Ph.D. Thesis, Fac. Sci, Ain Shams Univ., Cairo: Egypt, $261 \mathrm{pp}$.

Shata, A.: 1956, Structural development of the Sinai Peninsula, Egypt. Bull. Inst. Desert Egypt, 6, 2, 117-157.

Sholichin, M. and Prayogo, T.B.: 2019, Field identification of groundwater potential zone by VES method in south Malang, Indonesia. Int. J. Civ. Eng. Technol., 10, 2, 999-1009.

Steinitz, G., Bartov, Y. and Hunziker, J.C.: 1978, K\Ar agє determinations of some Miocene-Pliocene basalts ir Israel: Their significance to the tectonics of the rift valley. Geol. Mag. 115, 5, 329-340.

DOI: $10.1017 / \mathrm{S} 0016756800037341$ 